\title{
COMPARISON OF DIFFERENT CLINICAL AND METABOLIC PARAMETERS AMONG TYPE 2 DIABETIC PATIENTS WITH AND WITHOUT RETINOPATHY IN PRIMARY HEALTH CLINICS IN MEDAN CITY, NORTH SUMATERA, INDONESIA
}

RUSDIANA $^{1 *}$, SRY SURYANI WIDJAJA ${ }^{1}$, MILA HAYATI DAULAY $^{2}$, ALMAYCANO GINTING $^{3}$

\begin{abstract}
Background: The global prevalence of type 2 diabetes mellitus is increasing steadily and diabetic retinopathy is one of the microvascular complications of diabetes mellitus. This research aims to compare different clinical and metabolic parameters among type 2 diabetic patients with and without diabetic retinopathy.

Methods: This cross-sectional study was done at various primary health care centers in Medan city and the surrounding areas in North Sumatera from May to July 2020. Collected medical data included blood pressure, body mass index, duration of disease, family history and medical treatment. Laboratory data included blood glucose, glycated hemoglobin (HbA1c) and lipid profile. Diabetic retinopathy was detected by funduscopic examination by an ophthalmologist.

Results: Total patients were 88 and 26 had retinopathy. There was significant difference between the average blood pressure, blood glucose and HbA1C values among patients with type 2 diabetes mellitus with and without retinopathy $(p<0.005)$. But, there was no significant difference between the average body mass index (BMI), abdominal circumference and lipid profile.
\end{abstract}

Conclusion: Study showed that type 2 diabetic patients with retinopathy had increased blood glucose levels and $\mathrm{HbA1c}$ than patients without retinopathy.

Key words: Type 2 diabetes mellitus, blood sugar levels, HbA1c, retinopathy.

Received: 02 April 2020

Accepted: 12 June 2020

DOI: https://doi.org/10.3329/bjm.v31i2.48534

\section{Introduction}

Diabetic retinopathy is a major microvascular complication of diabetes ${ }^{1}$ and the prevalence of retinophaty increases with the duration of diabetes. More than $60 \%$ of patients with type 2 diabetes and almost all patients with type 1diabetes have some degree of retinopathy after 20 years of diabetes. ${ }^{3}$ Dyslipidemia is a complex disorder that involves both central, as well as organ-specific mechanisms. ${ }^{4-6}$ These include abnormal levels of lipids in the plasma that arise from a disproportion in metabolism, release and/ or uptake by the adipose tissue as well as inefficient lipid removal from blood circulation. In addition to central regulation, most cells in the body have tissuespecific control of lipid uptake, remodeling and elimination. ${ }^{7-9}$ Moreover, insulin resistance has been shown to promote dyslipidemia by elevating low density lipoprotein (LDL) cholesterol, total cholesterol, free fatty acids and triglycerides as well as decreasing high density lipoprotein (HDL) cholesterol and inhibiting reverse cholesterol transport genes. ${ }^{10,11}$ This study was designed to compare different clinical and metabolic parameters among type 2 diabetic patients with retinopathy and without retinopathy.

1. Departement of Biochemistry, Medical Faculty, Universitas Sumatera Utara, J1. dr. Mansur Kampus USU Medan 20155, Indonesia.

2. Departement of Physiology, Medical Faculty, Universitas Sumatera Utara, J1. dr. Mansur Kampus USU Medan 20155, Indonesia.

3. Departement of Clinical Pathology, Medical Faculty, Universitas Sumatera Utara, Jl. dr. Mansur Kampus USU Medan 20155, Indonesia.

Address of Correspondence: Rusdiana, Departement of Biochemistry, Medical Faculty, Universitas Sumatera Utara, J1. dr. Mansur Kampus USU Medan 20155, Indonesia. 


\section{Methods}

This cross-sectional study was done in Medan city and Primary Health Care Centers in Binjai and Stabat city, North Sumatera, Indonesia from May to July 2020. Collected medical data included blood pressure, body mass index, duration of disease, family history and medical treatment. Laboratory data included blood glucose, glycated hemoglobin (HbA1c) and lipid profile.

Eighty eight patients with type 2 diabetes mellitus were recruited, including 26 patients with retinopathy. Diabetic retinopathy was detected by the funduscopic examination by ophthalmologists and patients with known diabetics taking oral hypoglycaemic agents or managed with diet or using insulin for the glycaemic control were included in the study.

Permission from the institutional review committee was obtained. Patients were informed with the detail of the study and written consent was obtained from the patients before they participated in the study.

We measured height and weight with the subjects standing in light clothes. Body mass index (BMI) was calculated as the weight in kilograms divided by square of the height in meters $\left(\mathrm{kg} / \mathrm{m}^{2}\right)$. Blood pressure values were taken as the mean of two measurements after the subjects had been seated for at least five minutes. Subjects fasted overnight to provide a blood specimen. Blood samples were collected (using syringe) and transferred to Paramitha Clinical Laboratory immediately to be conducted fasting blood sugar, hemoglobin glycosylate and lipid profile. The examination of blood sugar levels were done by using hexokinase methods, hemoglobin glycosylate using HPLC methods, lipid profile using direct CHOD PAP and GPO PAP.

\section{Statistical Analysis}

SPSS version 24.0 (SPSS Inc., Chicago, Illinois) statistical software was used for statistical analysis. All the variables in this sample of the study were tested by Shapiro-Wilk, the normal distribution variables ( $p>0.005$ ) were tested by parametric correlation test, but the abnormal distribution variables $(\mathrm{p}<0.005)$ were tested by non-parametric test.

\section{Results}

Total patients were 88; 26 had retinopathy (males, 9) (age range, 45 - 79 years) and 62 did not have retinopathy (males, 17) (age range, 35 - 78 years) and the average age was not different $(\mathrm{p}>0.005)$ between two groups. Mean BMI and abdominal circumference of patients with and without retinopathy was not different but there was significant difference in blood pressure (Table I).

Regarding metabolic parameters, mean fasting blood glucose (retinopathy group, $320.81 \mathrm{mg} / \mathrm{dL}$ vs nonretinopathy group, $212.66 \mathrm{mg} / \mathrm{dL}$ ) and $\mathrm{HbA} 1 \mathrm{c}$ (retinopathy group $9.92 \%$ vs non-retinopathy group $8.25 \%$ ) were poor in patients with retinopathy than patients without retinopathy but lipid profile was not significantly different between two groups (Table II).

Table I

Characteristic of the samples $(N=88)$

\begin{tabular}{|c|c|c|c|c|c|}
\hline & $\mathrm{N}$ & Mean & Median & P-value & \\
\hline \multirow[t]{2}{*}{ Age (years) } & Diabetic Retinopathy & 26 & 57.73 & $58(45-79)$ & $P=0.669$ \\
\hline & Non-Diabetic Retinopathy & 62 & 56.82 & $55(35-78)$ & \\
\hline \multirow[t]{2}{*}{$\operatorname{BMI}\left(\mathrm{kg} / \mathrm{m}^{2}\right)$} & Diabetic Retinopathy & 26 & 24.60 & $23.80(17.63-46.44)$ & $\mathrm{P}=0.91$ \\
\hline & Non-Diabetic Retinopathy & 62 & 26.85 & $25.5(18.21-46.44)$ & \\
\hline \multirow[t]{2}{*}{ Abdominal circumference $(\mathrm{cm})$} & Diabetic Retinopathy & 26 & 91.12 & $90(68-121)$ & $\mathrm{P}=0.716$ \\
\hline & Non-Diabetic Retinopathy & 62 & 90.13 & $89(64-121)$ & \\
\hline \multirow[t]{2}{*}{ Systole (mmHg) } & Diabetic Retinopathy & 26 & 153 & $160(120-193)$ & $\mathrm{P}=0.036$ \\
\hline & Non-Diabetic Retinopathy & 62 & 142.71 & $142(98-203)$ & \\
\hline \multirow[t]{2}{*}{ Diastole $(\mathrm{mmHg})$} & Diabetic Retinopathy & 26 & 89.15 & $89(71-110)$ & $\mathrm{P}=0.115$ \\
\hline & Non-Diabetic Retinopathy & 62 & 85.26 & $85(60-112)$ & \\
\hline
\end{tabular}


Table II

Metabolic parameters of patients with $(n=26)$ and without $(n=62)$ diabetic retinopathy

\begin{tabular}{llcccccc}
\hline & & $\mathrm{N}$ & Mean & Median & Std. Deviation & Std. Deviation & P-value \\
\hline Cholesterol & Diabetic Retinopathy & 26 & 221.73 & $227(146-321)$ & 48.720 & 48.720 & $\mathrm{P}=0.222$ \\
(mg/dL) & Non-Diabetic Retinopathy & 62 & 208.42 & $210.50(111-277)$ & 38.284 & 38.284 & \\
HBa1c (\%) & Diabetic Retinopathy & 26 & 9.92 & $9.85(4.7-19.5)$ & 3.8121 & 3.8121 & $\mathrm{P}=0.044$ \\
& Non-Diabetic Retinopathy & 62 & 8.25 & $.8(5-13.4)$ & 2.2477 & 2.2477 &. \\
BSL (mg/dL) & Diabetic Retinophaty & 26 & 320.81 & $326(73-610)$ & 158.003 & 158.003 & $\mathrm{P}=0.003$ \\
& Non-Diabetic Retinopathy & 62 & 212.66 & $180.5(80-492)$ & 106.745 & 106.745 & \\
Triglycerides & Diabetic Retinophaty & 26 & 246.04 & $206(87-662)$ & 129.073 & 129.073 & $\mathrm{P}=0.144$ \\
(mg/dL) & Non-Diabetic Retinopathy & 62 & 204.39 & $188(49-408)$ & 91.502 & 91.502 & \\
LDL (mg/dL) & Diabetic Retinopathy & 26 & 124.23 & $121(65-213)$ & 38.732 & 38.732 & $\mathrm{P}=0.730$ \\
& Non-Diabetic Retinopathy & 62 & 121.27 & $124(50-181)$ & 30.161 & 30.161 & \\
HDL (mg/dL) & Diabetic Retinophaty & 26 & 46.88 & $45(24-77)$ & 14.146 & 14.146 & $\mathrm{P}=0.812$ \\
& Non-Diabetic Retinopathy & 62 & 47.61 & $46(29-77)$ & 9.780 & 9.780 & \\
\hline
\end{tabular}

\section{Discussion}

In this study, we have compared different parameters of type 2 diabetic patients with retinopathy and without retinopathy. This research showed that there was no significant difference in BMI and waist circumference in two groups. Many epidemiologic studies have explored the association of diabetic retinopathy with BMI or anthropometric parameters, but the conclusions have been contradictory. Recent studies conducted in Asian populations have reported an inverse association between BMI and the risk of retinopathy, suggesting a protective role. ${ }^{12}$. Research by Lu $\mathrm{J}$ et al showed that overweight patients had lower diabetic retinopathy prevalence than normal-weight individuals, which may be attributable to better â cell function in overweight patients. ${ }^{13}$ And research by Hwang et.al showed that an independent association of body fat with diabetic retinopathy and provides evidence that sex differences in body fat composition may affect the prevalence and progression of diabetic retinopathy. ${ }^{14}$

Dysfunction of blood vessel endothelial cells is an important factor in the pathogenesis of vascular complications in diabetes mellitus, where vascular dysfunction is mainly caused by elevated blood sugar levels that occur chronically. With the onset of hyperglycemia, it directly changes endothelial function or affects endothelial cells functioning indirectly by affecting the growth factor pathways, cytokines and vasoactive agents. ${ }^{15}$ Hyperglycemia was considered to play an important role in the pathogenesis of retinal microvascular damage too. Multiple metabolic pathways have been implicated in hyperglycemia- induced vascular damage including the polyol pathway, advanced glycation end products (AGEs) accumulation, the protein kinase $\mathrm{C}(\mathrm{PKC})$ pathway and the hexosamine pathway. ${ }^{16}$ The earliest responses of the retinal blood vessels to hyperglycemia are dilatation of blood vessels and blood flow changes. These changes are considered to be metabolic autoregulation to increase retinal metabolism in diabetic subjects. ${ }^{17}$ Our study showed that there was a significant difference in average blood sugar levels in diabetic retinopathy than those without retinopathy. There was a difference in average $\mathrm{HbA} 1 \mathrm{c}$ also. This study is similar to the research by Ebru, who found that a significant correlation between the mean blood glucose, HbA1c, and total cholesterol, and then in his research there was no significant association between serum lipids and the severity of diabeticum retinophay. ${ }^{18}$ Our research at both of the groups' samples showed the mean $\mathrm{HbA} 1 \mathrm{c}$ value $>6.5 \%$, it means that both of the groups were uncontrolled type 2 diabetes mellitus category. We know that HbA1c was the best available biochemical parameter to assess the long-term metabolic control in patients with diabetes. HbA1c levels are closely associated with the response to treatment and the risk of developing complications and hence it provides the evidence-based marker with which we can assess the chances of developing diabetic complications. It provides information about the overall control of glucose in the previous 6-8 weeks. ${ }^{19}$ Research by Sadhana Sewak concluded that the value of HbA1c showed an increasing trend as the severity of diabetic retinopathy increases. ${ }^{20}$ The good glycemic control of diabetes with a target $\mathrm{HbA} 1 \mathrm{c}$ of $7.0 \%$. The 
other research concluded that a threshold of the risk for incident retinopathy at a $6.5 \% \mathrm{HbA} 1 \mathrm{c}$ level. Regular ophthalmic screening for diabetic retinopathy changes will reduce morbidity due to diabetic retinopathy and then they recommend maintaining $\mathrm{HbA} 1 \mathrm{c}$ levels below $7.5 \%$ which may reduce the risk of development and progression of diabetic retinopathy. ${ }^{21}$ Research by Lokesh showed as the HbA1c level increases the severity of the diabetic retinopathy also increases. And also, patients who had microalbuminuria and longer the duration of diabetes higher the chances of microvascular complications. Hence HbA1c can be used as a useful tool to assess the long-term control of diabetes mellitus and hence the development of diabetic retinopathy. ${ }^{22}$

Our study showed that there were no difference average cholesterol, triglycerides, LDL, and HDL levels among retinopathy group and non-retinopathy group but both of the groups showed that an increasing the cholesterol and triglycerides levels were compared normal value. The other research found that did not find obvious differences in TG, TC, and HDL-C levels between patients with diabetic retinopathy and without diabetic retinopathy. However, a little higher levels of LDL-C with borderline statistical significance were observed in patients with diabetic retinopathy. In addition, whether any association existed between serum lipids and retinopathy progression was unknown, but the fenofibrate treatment should be recommended since it could prevent the diabetic retinopathy progression through lipid-modulating independent pathways. In the future, more prospective large-scale studies would be needed to further investigate the association between serum lipids and diabetic retinopathy. As well, the mechanisms of fenofibrate involved in the control of diabetic retinopathy progression needed further investigation. ${ }^{23}$

Patients with diabetic dyslipidemia were shown to have a higher frequency of acquiring retinal irregularities. ${ }^{24}$ However, unlike macrovascular complications, where the direct correlation between pathology and circulating lipid levels is well established ${ }^{25}$ the role of circulating lipids in microvascular complications is still controversial. Indeed, Wisconsin Epidemiologic Study of Diabetic Retinopathy found no association between total cholesterol or HDL and incidence of diabetic retinopathy or macular edema, while there was a modest association between higher levels of HDL and decreased prevalence of proliferative diabetic retinophaty. ${ }^{26}$

\section{Conclusion}

In our conclusion, we found that lood pressure, blood sugar levels, and $\mathrm{HbA} 1 \mathrm{c}$ levels were higher in type 2 diabetic patients who had diabetic retinopathy than those who did not have diabetic retinopathy. These factors should be addressed for reduction of slowing diabetic complications including retinopathy.

Conflict of Interests: There are no conflicts of interest.

\section{Acknowledgments}

The authors gratefully acknowledge that the present research is supported by the Ministry of Research and Technology and Higher Education Republic Indonesia. The support is under the research grant TALENTA USU of the Year 2020.

\section{References}

1. Cheung N, Mitchell P, Wong YT. Diabetic retinopathy. Lancet 2010. 376(9735):124-136. https://doi.org/ 10.1016/S0140-6736(09)62124-3

2. Klein R, Klein BE, Moss SE, Cruickshanks KJ. The Wisconsin Epidemiologic Study of Diabetic Retinopathy: XVII. The 14-year incidence and progression of diabetic retinopathy and associated risk factors in type 1 diabetes. Ophthalmology 1998. 105(10):1801-1815. https://doi.org/10.1016/S0161-6420(98)91020-X

3. Wong TY, Klein R, Islam FM, Cotch MF, Folsom AR, Klein BE, et al. Diabetic retinopathy in a multi-ethnic cohort in the United States. Am J Ophthalmol 2006. 141(3):446-455. https://doi.org/10.1016/ j.ajo.2005.08.063. PMid:16490489 PMCid: $\mathrm{PMC} 2246042$

4. Chen W, Esselman WJ, Jump DB, Busik JV. Antiinflammatory effect of docosahexaenoic acid on cytokine-induced adhesion molecule expression in human retinal vascular endothelial cells. Invest Ophthalmol Vis Sci. 2005. https://doi.org/10.1167/ iovs.05-0601 PMid:16249517 PMCid:PMC1378111. 46(11):4342-7. Epub 2005/10/27. DOI :46/11/4342 [pii] 10.1167/iovs. 05-0601. [PubMed: 16249517]

5. Tikhonenko M, Lydic TA, Wang Y, Chen W, Opreanu M, Sochacki A, et al. Remodeling of retinal Fatty acids in an animal model of diabetes: a decrease in long-chain polyunsaturated fatty acids is associated with a decrease in fatty acid elongases Elov12 and Elovl4. Diabetes. 2010. https://doi.org/10.2337/db09-0728. PMid:19875612 PMCid:PMC2797925

59(1):219-27. Epub 2009/10/31. DOI:10.2337/ db090728 db09-0728 [pii]. [PubMed: 19875612]

6. Yu Y, Lyons TJ. A lethal tetrad in diabetes: hyperglycemia, dyslipidemia, oxidative stress, and endothelial dysfunction. Am J Med Sci. 2005; 330(5):227-32. [PubMed: 16284482]. https://doi.org/ $10.1097 / 00000441-200511000-00005$. PMid: 16284482

7. Tikhonenko M, Lydic TA, Wang Y, Chen W, Opreanu M, Sochacki A, et al. Remodeling of retinal Fatty acids in an animal model of diabetes: a decrease in long-chain 
polyunsaturated fatty acids is associated with a decrease in fatty acid elongases Elovl2 and Elovl4. Diabetes. 2010 https://doi.org/10.2337/db09-0728. PMid:19875612 PMCid:PMC2797925. 59(1):219-27. Epub 2009/10/31. DOI:10.2337/ db09-0728 db090728 [pii]. [PubMed: 19875612]

8. Yu Y, Lyons TJ. A lethal tetrad in diabetes: hyperglycemia, dyslipidemia, oxidative stress, and endothelial dysfunction. Am J Med Sci. 2005; 330(5):227-32. [PubMed: 16284482]. https://doi.org/ $10.1097 / 00000441-200511000-00005$ PMid:16284482

9. Mast N, Reem R, Bederman I, Huang S, DiPatre PL, Bjorkhem I, et al. Cholesteronoic Acid is an important elimination product of cholesterol in the retina: comparison of retinal cholesterol.

10. Ginsberg HN, Zhang YL, Hernandez-Ono A. Regulation of plasma triglycerides in insulin resistance and diabetes. Arch Med Res. 2005; 36(3):232-40. DOI: 10.1016/j.arcmed.2005.01.005 [PubMed: 15925013]. https://doi.org/10.1016/j.arcmed.2005.01.005 PMid:15925013

11. Goff DC Jr, D’Agostino RB Jr, Haffner SM, Otvos JD. Insulin resistance and adiposity influence lipoprotein size and subclass concentrations. Results from the Insulin Resistance Atherosclerosis Study. Metabolism. 2005; 54(2):264-70. DOI: 10.1016/j.metabol. 2004.09.002 [PubMed: 15690322]. https://doi.org/ 10.1016/j.metabol.2004.09.002. PMid:15690322

12. Rooney D, Lye WK, Tan G, Lamoureux EL, Ikram MK, Cheng CY, et al. Body mass index and retinopathy in Asian populations with diabetes mellitus. Acta Diabetol. 2015;52:73-80. https://doi.org/10.1007/s00592-0140602-2 PMid:24880522

13. Lu J, Hou X, Zhang L, et al. Association between body mass index and diabetic retinopathy in Chinese patients with type 2 diabetes. Acta Diabetol. 2015;52(4):701708. DOI:10.1007/s00592-014-0711-y. https:// doi.org/10.1007/s00592-014-0711-y PMid:25604042

14. Hwang, I.C., Bae, J.H. \& Kim, J.M. Relationship between body fat and diabetic retinopathy in patients with type 2 diabetes: a nationwide survey in Korea. Eye 33, 980987 (2019). https://doi.org/10.1038/s41433-0190352-z. https://doi.org/10.1038/s41433-019-0352-z. PMid:30760896 PMCid:PMC6707327

15. Schalkwijk CG, Stehouwer CD. Vascular complications in diabetes mellitus: the role of endothelial dysfunction. Clin Sci (Lond) 2005;109(2): 143-159. https://doi.org/ 10.1042/CS20050025 PMid:16033329

16. Brownlee, M. The pathobiology of diabetic complications: A unifying mechanism. Diabetes 2005; 54:1615-1625. [CrossRef] [PubMed]. https://doi.org/ 10.2337/diabetes.54.6.1615 PMid:15919781

17. Bek, T. Diameter changes of retinal vessels in diabetic retinopathy. Curr. Diabetes Rep. 2017, 17, 82.
[CrossRef] [PubMed]. https:/ / doi.org/10.1007/s11892017-0909-9 PMid:28791532

18. Cetin EN, Bulgu Y, Ozdemir S, et al. Association of serum lipid levels with diabetic retinopathy. Int $\mathrm{J}$ Ophthalmol. 2013;6(3):346-349. Published 2013 Jun 18. DOI :10.3980/j.issn.2222-3959.2013.03.17

19. Andrew farmer. Monitoring Diabetes In Holt RIG, Cockram CS, Flyvbjerg Goldstein BJ, eds. Textbook of Diabetes.5th ed. Wiley Blackwell;2017:374-384. https:/ /doi.org/10.1002/9781118924853.ch27

20. Sadhana Sewak, et al. Association of Level of HbA1c with Severity of Diabetic Retinopathy. JMSCR Volume 06 Issue 01 January 2018. DOI: https://dx.doi.org/ 10.18535/jmscr/v6i1.22. https://doi.org/10.18535/ jmscr/v6i1.22

21. Tsugawa $Y$, Takahashi O, Meigs JB, Davis RB, Imamura F, Fukui T, et al. New diabetes diagnostic threshold of hemoglobin $A(1 \mathrm{c})$ and the 3-year incidence of retinopathy. Diabetes. 2012 Dec;61(12):3280-4. DOI: 10.2337/db12-0103. Epub 2012 Aug 13. PMID: 22891221; PMCID: PMC3501847. https://doi.org/ 10.2337/db12-0103 PMid:22891221 PMCid:PM C3501847

22. Lokesh S, Shivaswamy S. Study of HbA1C levels in patients with type 2 diabetes mellitus about to with concerning diabetic retinopathy in Indian population. Int J Adv Med 2018;5:1397-401. https://doi.org/ 10.18203/2349-3933.ijam20184686

23. Zhou Y, Wang C, Shi K, Yin X. Relationship between dyslipidemia and diabetic retinopathy: A systematic review and meta-analysis. Medicine (Baltimore). 2018 Sep;97(36):e12283. https://doi.org/10.1097/ MD.0000000000012283. PMid:30200172 PMCid:PMC6133445. doi: 10.1097/MD.00000000000 12283. PMID: 30200172 ; PMCID: PMC6133445. https: / /doi.org/ 10.1097/MD.0000000000012283. PMid:30200172 PMCid:PMC6133445

24. Sacks FM, Hermans MP, Fioretto P, Valensi P, Davis T, Horton E, et al. Association between plasma triglycerides and high-density lipoprotein cholesterol and microvascular kidney disease and retinopathy in type 2 diabetes mellitus: a global case-control study in 13 countries. Circulation. 2014; 129(9):999-1008. DOI: 10.1161/CIRCULATIONAHA. 113.002529 [PubMed: 24352521]. https://doi.org/10.1161/ CIRCULATIONAHA. 113.002529. PMid:24352521

25. Group AS, Group AES, Chew EY, Ambrosius WT, Davis $\mathrm{MD}$, Danis RP, et al. Effects of medical therapies on retinopathy progression in type 2 diabetes. $\mathrm{N}$ Engl $\mathrm{J}$ Med. 2010; 363(3):233-44. DOI: 10.1056/ NEJMoa1001288 [PubMed: 20587587. https:// doi.org/10.1056/NEJMoa1001288. PMid:20587587 PMCid:PMC4026164

26. Klein BE, Myers CE, Howard KP, Klein R. Serum Lipids and Proliferative Diabetic Retinopathy and Macular Edema in Persons With Long-term Type 1 Diabetes Mellitus: The Wisconsin Epidemiologic Study of Diabetic Retinopathy. JAMA ophthalmology. 2015; 133(5):50310. https://doi.org/10.1001/jamaophthalmol.2014. 5108. PMid:25502808 PMCid:PMC4433425. 